\title{
SOME HARDY-TYPE INEQUALITIES IN BANACH FUNCTION SPACES
}

\author{
SORINA BARZA, LJUdMIla NiKOlova, LARS-ERIK PERSSON \\ AND MARKOS YIMER
}

Abstract. Some new inequalities of Hardy-type in Banach function space settings are proved and discussed. In particular, these results generalize and unify several classical Hardy-type inequalities. Some results are new also in the classical situation.

Mathematics subject classification (2020): Primary 26D10; Secondary 26D15, 26D20, 47B38.

Keywords and phrases: Integral inequalities, Hardy's inequality, Pólya-Knopp's inequality, HardyKnopp's inequality, Banach function spaces.

\section{REFERENCES}

[1] S. Barza And L. Nikolova, Carleson- and Hardy-type inequalities in some Banach function spaces, Nonlinear studies 26 (2019), no. 4, 755-766.

[2] C. Bennett And R. Sharpley, Interpolation of Operators, Academic Press, Inc., Boston, MA, 1988.

[3] E. I. BEREZHNOI, Inequalities with weights for Hardy operators in function spaces, In: Function Spaces (Poznań, 1989), 75-79, Teubner-Texte Math., 120, Teubner, Stuttgart (1991).

[4] A. ČIŽMeŠIJA, J. PeČARIĆ AND L.-E. Persson, On strengthened Hardy and Pólya-Knopp inequalities, J. Approx. Theory 125 (2003), no. 1, 74-84.

[5] G. H. HARDY, Notes on some points in the integral calculus, LX. An inequality between integrals, Messenger of Math., 54 (1925), 150-156.

[6] G. H. HARDY, Notes on some points in the integral calculus, LXIV, Messenger of Math., 57 (19271928), 12-16.

[7] G. H. Hardy, J. E. Littlewood and G. Pólya, Inequalities, Second Edition, Cambridge University Press 1952 (First Edition 1934).

[8] S. Kaijser, L. Nikolova, L.-E. Persson, And A. Wedestig, Hardy-type inequalities via convexity, Math. Inequal. Appl., 8 (2005), no. 3, 403-417.

[9] K. KNopp, Über Reihen mit positivern Gliedern, J. London Math. Soc., 3 (1928), 205-211.

[10] S. G. KreǏn, E. M. Semenov And Ju. I. Petunin, Interpolation of linear operators, Nauka, Moscow, 1978 (Russian), English transl. in Amer. Math. Soc., Providence, 1982.

[11] K. KRULIĆ, Generalizations and Refinements of Hardy's Inequality, $\mathrm{PhD}$ thesis, University of Zagreb, 2010.

[12] K. Krulić, J. PeČArić And L.-E. Persson, Some new Hardy type inequalities with general kernels, Math. Inequal. Appl. 12 (2009), no. 3, 473-485.

[13] K. Krulić Himmelreich, J. PeČArić, And D. PokaZ, Inequalities of Hardy and Jensen, Monographs in Inequalities 6, Zagreb, Element, 2013.

[14] A. Kufner, L. Maligranda And L.-E. Persson, The Hardy Inequalities. About its History and Some Related Results, Vydavatelsky Servis Publishing House, Pilsen, 2007.

[15] A. Kufner, L.-E. Persson And N. SAmKo, Weighted Inequalities of Hardy Type, Second Edition, World Scientific Publishing Co., New Jersey, 2017.

[16] J. Lindenstrauss And L. TZAFriri, Classical Banach spaces II, Springer-Verlag, Berlin, Heidelberg, New York, 1979.

[17] L. Nikolova, L.-E. Persson AND S. VArošAneC, A new look at classical inequalities involving Banach lattice norms, J. Inequal. Appl. (2017), 2017:302. 
[18] J. A. Oguntuase, L.-E. Persson And E. K. Essel, Multidimensional Hardy-type inequalities with general kernels, J. Math. Anal. and Appl., 348 (2008), 411-418.

[19] B. OpIC And A. Kufner, Hardy-type inequalities, Pitman Research Notes in Mathematics Series, Longman Scientific and Technical, Harlow, 1990.

[20] L.-E. PERSSON AND N. SAMKO, What should have happened if Hardy had discovered this?, J. Inequal. Appl. 2012, 2012:29,20pp. 